\title{
Article \\ Lifestyle and dietary habits of high school going students in north-eastern part of Bangladesh during COVID-19 Pandemic
}

\author{
Ahsan Habib Sunny, Muhammad Sakib Ibtidha Chowdhury and Mohammad Ohid Ullah* \\ Department of Statistics, Shahjalal University of Science and Technology (SUST), Sylhet, Bangladesh \\ *Corresponding author: Mohammad Ohid Ullah, Dept. of Statistics, SUST, Sylhet, Bangladesh. E-mail: ohid- \\ sta@sust.edu
}

Received: 14 November 2021/Accepted: 21 December 2021/ Published: 30 December 2021

Copyright (C) 2021 Ahsan Habib Sunny et al. This is an open access article distributed under the Creative Commons Attribution 4.0 International License (https://creativecommons.org/licenses/by/4.0/), which permits unrestricted use, distribution, and reproduction in any medium, provided the original work is properly cited.

\begin{abstract}
Food habits and lifestyle are risk factors of health problem. Moreover, adulthood health depends on adolescent health. A cross-sectional study was designed to know the lifestyle and dietary habits of high school going students during the pandemic. A semi-structured questionnaire was developed and data were collected randomly from the students. Descriptive analysis, logistic regression model and factor analysis were used to analyze the data. The results revealed that most of the students fairly follow the lifestyle and dietary habits. It is observed that students who read newspapers daily are $75 \%$ more likely to follow the dietary pattern. During a pandemic, most of the high school going students in north-eastern part of Bangladesh were taking protein types food (communality $=0.724$ ) and vegetables (communality=0.694) maximum times per week. Students increased their sleeping hours (communality $=0.784$ ) and intended to do job (communality=0.781) to help their families during the COVID-19. Moreover, the study also observed some important lifestyle factors like- watching mobile/laptop, connecting social media etc. and most of the students (45\%) thought that electronic devices hamper their normal education. Taken together, the findings of this study may be useful to make awareness in the society about the healthy and unhealthy lifestyle as well as food habits. Government and Non-Government organizations should take proper nutritional and health related programs in the high schools that provide healthy lifestyle and food habits for improving the public health sector in Bangladesh.
\end{abstract}

Keywords: students; lifestyle; dietary habits; COVID-19; Bangladesh

\section{Introduction}

Students of high school mainly refer to teenagers and this period is the interim phase from childhood to adulthood which is the most important part of human life known as adolescence. Though being identified as relatively healthy period, each year 2.6 million teenagers die in the whole world. Those who follow a healthy lifestyle can improve behavior and sustain their well-being but many teenagers' raises unhealthy habits (such as inadequate nutritional intake, rest, and exercise) and risky behaviors (such as tobacco and drug use) that may lead to an unhealthy state (Lean, 2010). At this stage of life, they may have to cope with many changes to their bodies, behavior, and their feelings. On the other hand, the word "Lifestyle" indicates someone's way of living which effects person's health through lifestyle factors such as physical activity, watching TV, using mobile and internet, eating habits, substance abuse (e.g., alcohol and tobacco), and sleeping time (Serdula et al., 1993). A study depicts that three things - changing eating habits, changing combination of time and reduction in duration of exercise in student's lifestyle may significantly effect on students' tension (Cappuccio et al., 2008). According to the world health organization (WHO) early deaths and diseases happens because of negative 
health behaviors such as smoking, avoiding exercise, unhealthy sexual activity, and violence and a study shows that in Turkish Society young people don't give much interest in physical activity and healthy diet (Rennie et al., 2005). Self-harming attitude has been increasing nowadays among teenagers which are a powerful cause of suicide. Although in different countries government focuses on healthy nutrition and appropriate exercise for the teenager, the amount of fast food with high fat and sugar that is in taken by youths are increasing day by day. With this, the amount of physical exercise is decreasing among teenagers and activities like watching TV, playing online games are increased (Brug et al., 2012; Ko et al., 2008; Bener et al., 2019). Healthy behaviors should be introduced to them early in childhood which helps them to maintain those habits from childhood throughout their adulthood and being familiarized with healthy routines depends on their gender, socioeconomic status and availability of educational programs (Çelebi et al., 2017; Musaiger et al., 2011; Judy et al., 2005; Nahas et al., 2009; Anderson et al., 2006; Zaal et al., 2009; Janssen et al., 2004; Cotte, 1998). On the other hand, it has been observed that adolescences are seen to be more related with crimes than past and $43 \%$ of murders in each year globally happen among young people (Sultana et al., 2011). Some studies evidently show that insufficient sleep results in dizziness in school and examination hall, irritation, absurd behavior etc. (OhidUllah et al., 2014; Dinges, 1995; Garaulet et al., 2011; Carskadon, 1990; Wolfson et al., 1998; Choi et al., 2009; Ekinci et al., 2014).

Studies reveal that increased television viewing is linked negatively with fruits and vegetables consuming and positively with the consumption of energy drinks and fast foods (Pearson et al., 2011). Nowadays breakfast skipping become a common habit of school going adolescents(Niemeier et al., 2006; Serra-Majem et al., 2004; Law et al., 2013). At the same time, they are getting used to consuming fast food and low-quality food. One of the reasons behind this habit is lacking of time to prepare food at home while there are many fast-food outlets (Wickramasinghe et al., 2004). A study shows that on an average, adolescents visit to fast food outlets twice a week and about one-third of the away from home meals consumed by adolescents are fast foods(Lin et al., 1999) and the trend of consuming food from restaurant and fast-food outlets are increasing drastically(Nielsen $e t$ al., 2002). A very concerning matter is that the high school going students consume foods with high fat when they are eating fruits and vegetables lower than recommended (French et al., 2010) and many studies showed that this unhealthy practice is more common in males compare to female (Fagerli et al., 1999; Rappoport et al., 1993; Rathi et al., 2017; Cavadini et al., 2000).

In Bangladesh one-third of total population are teenagers and according to United Nations Population Fund (UNFPA 2014), by 2050 young people will be 10-19\% of total population. This information indicates that more attentions are required to fulfill requirements of youngsters without delay (Swinburn et al., 2004).

Unhealthy dietary habits are linked to the dramatic increases of several chronic diseases (cardiovascular diseases, cancer, and type 2 diabetes) that are the causes of mortality in both developed and developing countries in the last several decades. Many studies (Neumark-Sztainer et al., 1998; Munoz et al., 1997; Johnson et al., 1994; Bhuiyan et al., 2013; Uddin et al., 2017; Ahmed et al., 2006; Khan et al., 2017; Banik et al., 2020; Kundu et al., 2020) have been found that adolescents have poor dietary habits; therefore, modification of adolescent eating behavior should be developed. A cross-sectional study (OhidUllah et al., 2018; Khan et al., 2017) also conducted on obesity and food habits of primary school going children in Sylhet city. However, to the best of our knowledge no study has been conducted to know the lifestyle and dietary patterns of high school going students in North-eastern part of Bangladesh. Therefore the studyis designed to detect the dietary patterns and lifestyle of adolescents in Sylhet division during the pandemic.

\section{Materials and Methods}

\subsection{Data}

Primary data were collected randomly from high school students of the Sylhet division. Data were collected from total 509 students during November 2020 to October 2021. As the schools didn't open because of pandemic, some data were collected s via online, some data by visiting the households and the areas of the selected schools. The questionnaire (semi-structured) consist demographic (age, sex, etc.), socio-economic characteristics (own house or rented house, how they come to school, existence of private tutor or coaching etc.), lifestyle characteristics (smoking, sedentary activities, physical activities etc.) and frequency of dietary intake of several food items (focusing balanced diet) daily/weekly/monthly dietary habits. For example, frequency of drinking milk- options: none or 1 glass/month, 1 glass/week, 2-6 glasses/week, 1 glass/day, 2-3 glasses/day etc. 


\subsection{Statistical analysis}

Descriptive analysis (percentage) and logistic regression model have been used in the data. To know the important factors of dietary pattern and lifestyle, factor analysis was also used in this study. SPSS software was used for data analysis.

\section{Results and Discussion}

Initially several frequency tables have been made up for assessing the socio-demographic characteristics, dietary habits, and lifestyle behaviors of secondary school students.

From Table 1, it was observed that male and female were $50.1 \%$ and $49.9 \%$ respectively. It was also observed that more than half of the students were Muslims, only $1.0 \%$ were Buddhist and the rest belong from Hinduism religion. Total 58\% students were from urban area and remaining from rural area. Most of the students' fathers were primary passed $(24.1 \%)$ followed by secondary passed $(21.1 \%)$ and graduated $(21.1 \%)$ and in case of mother, also most of them were primary passed (34.9\%) followed by secondary passed (22.4\%).It was found that $37.9 \%$ of students' fathers were businessman and $22.8 \%$ were farmers. Most of the students' mothers were housewives (85.4\%). The results revealed that within pandemic around 6\% (20000-50000Taka) students' family income was reduced, almost similar case in students' family income above 50000 Taka. Moreover, it was found that $75.8 \%$ of our study participants have their own house.

From Table-2, it was observed that $22.6 \%$ of the respondents taking breakfast regularly and about half of them never take breakfast. In case of consuming protein type foods, $34.7 \%$ of respondents were regular and $26 \%$ of them were never consumed protein type foods. Around 50\% of our respondents were irregular in eating vegetables, fruits and junk foods and almost half of the respondents were also irregular in taking milk or dairy food when a notable number of them also never consume these foods. It was also found that about three quarters of the students drink two to three liters water per day.

From Table 3, it was found that around half of the students were underweighted when $46 \%$ had normal BMI (Body mass Index), $4.9 \%$ of them were over weighted and $0.4 \%$ of them are obese. Above $50 \%$ of the participants do not follow any dietary pattern. In case of physical exercise, above $55 \%$ of the students practice this habit when about $50 \%$ of the students were involved in playing sports. On the contrary, most of the students were not involved in any extra-curricular activities and the rate was $79.1 \%$. It was found that about half of the students were active in social media. Again, $45 \%$ students think that electronic devices hamper their normal education when $32.2 \%$ think that electronic devices have no negative effect on their normal education. To know the factors that are influenced to follow dietary pattern (Yes/No), multiple logistic regression model was used.

From the Table 4, it was observed that practice of dietary habit had increased $30 \%$ during the pandemic. The strongest predictor was found in this model was "reading newspapers". The odds ratio in this case was 1.749 which indicated that those who read newspapers on daily basis were almost $75 \%$ more likely to follow a dietary pattern. Apart from this, it was notable that $24.5 \%$ respondents who were connected to social media more likely to follow dietary pattern and, who watch television in a regular basis were less like to maintain any dietary routine.

To find out the important factors of lifestyle and dietary pattern factor analysis was used. It was found that most of the students of high school going students in north-eastern part of Bangladesh were taking protein types food (communality $=0.724$ ) and vegetables (communality $=0.694)$ maximum times per week. It was also observed in lifestyle dimension that students were highly attentive to their study (communality $=0.786$ ), increasing sleeping hours (communality $=0.784$ ), intend to do job (communality $=0.781$ ) during the COVID pandemic. Besides these, it was also found some important factors like increasing sleeping hours, watching mobile/laptop, connecting social media etc.

Usually, adolescent food habits and life style may lead the adulthood habits and lifestyle. Unhealthy lifestyle may be cause of different diseases like cardiovascular diseases, cancer, type-2 diabetes, COVID-19 etc. According to the study findings, it was observed that secondary school students embrace healthy lifestyle behaviors fairly. However, we found that some of the students are irregular in practicing healthy diet. Previous studies supported these results (Musaiger, et al., 2014) (Kilani, et al., 2013) (Rathi, et al., 2017). It was observed that around 6\% students' monthly family income was reduced during COVID-19 pandemic and most of the students think electronic devices hamper their normal education. We also observed that reading newspaper and connecting social media plays positive role on following dietary pattern students who read newspapers daily and connected with social media are more likely to follow dietary pattern. On the other hand students who are watching television more they are less likely to follow dietary pattern.

Changes in lifestyle factors, such as increasing the intake of protein type foods, vegetables, fruits as well as reducing intake of junk food, were important determinants of self-rated health among students. The results 
claims that not only just any specific factor but multiple lifestyle factors are dominating unhealthy practice among young people like secondary school going students. However, during COVID-19 pandemic, students increased their sleeping time, intend to do job, watching television, connecting social media using mobile/computer.

Table 1. Socio-demographic characteristics of the students.

\begin{tabular}{|c|c|c|}
\hline Variables & Categories & Frequency $(\%)$ \\
\hline \multirow[t]{2}{*}{ Gender } & Male & $255(50.1 \%)$ \\
\hline & Female & $254(49.9 \%)$ \\
\hline \multirow[t]{4}{*}{ Religion } & Islam & $278(54.7 \%)$ \\
\hline & Hinduism & $225(44.3 \%)$ \\
\hline & Buddhism & $5(1.0 \%)$ \\
\hline & Christianity & $0(0.00 \%)$ \\
\hline \multirow[t]{2}{*}{ Residence } & Urban & $296(58 \%)$ \\
\hline & Rural & $214(42 \%)$ \\
\hline \multirow[t]{5}{*}{ Father's Education } & Primary & $121(24.1 \%)$ \\
\hline & Secondary & $106(21.1 \%)$ \\
\hline & Intermediate & $97(19.3 \%)$ \\
\hline & Graduate & $106(21.1 \%)$ \\
\hline & None & $72(14.3 \%)$ \\
\hline \multirow[t]{5}{*}{ Mother's Education } & Primary & $176(34.9 \%)$ \\
\hline & Secondary & $113(22.4 \%)$ \\
\hline & Intermediate & $78(15.5 \%)$ \\
\hline & Graduate & $66(13.1 \%)$ \\
\hline & None & $71(14.1 \%)$ \\
\hline \multirow[t]{5}{*}{ Father's Occupation } & Business & $191(37.9 \%)$ \\
\hline & Govt. Job & $51(10.1 \%)$ \\
\hline & Private Job & $59(11.7 \%)$ \\
\hline & Farmer & $115(22.8 \%)$ \\
\hline & Others & $88(17.5 \%)$ \\
\hline \multirow[t]{5}{*}{ Mother's Occupation } & Business & $8(1.6 \%)$ \\
\hline & Govt. Job & $26(5.1 \%)$ \\
\hline & Private Job & $22(4.3 \%)$ \\
\hline & Housewife & $434(85.4 \%)$ \\
\hline & Others & $18(3.5 \%)$ \\
\hline \multirow[t]{3}{*}{ Monthly family income before pandemic } & Below 20000 & $161(32.7 \%)$ \\
\hline & $20000-50000$ & $221(44.8 \%)$ \\
\hline & Above 50000 & $111(22.5 \%)$ \\
\hline \multirow[t]{3}{*}{ Monthly family income within pandemic } & Below 20000 & $219(44.8 \%)$ \\
\hline & $20000-50000$ & $190(38.9 \%)$ \\
\hline & Above 50000 & $80(16.4 \%)$ \\
\hline \multirow[t]{2}{*}{ Own House } & Yes & $382(75.8 \%)$ \\
\hline & No & $122(24.2 \%)$ \\
\hline
\end{tabular}


Asian J. Med. Biol. Res. 2021, 7 (4)

Table 2. Dietary habits of the students.

\begin{tabular}{|l|l|l|}
\hline Variables & Categories & Frequency $(\%)$ \\
\hline \multirow{5}{*}{ Taking Breakfast } & Irregular & $155(30.9 \%)$ \\
\cline { 2 - 3 } & Regular & $113(22.6 \%)$ \\
\cline { 2 - 3 } & Never & $233(46.5 \%)$ \\
\hline \multirow{5}{*}{ Taking Protein type foods } & Irregular & $199(39.3 \%)$ \\
\cline { 2 - 3 } & Regular & $176(34.7 \%)$ \\
\cline { 2 - 3 } & Never & $132(26 \%)$ \\
\hline \multirow{5}{*}{ Taking Fruits } & Irregular & $260(51.1 \%)$ \\
\cline { 2 - 3 } & Regular & $142(27.9 \%)$ \\
\cline { 2 - 3 } & Never & $107(21 \%)$ \\
\hline \multirow{5}{*}{ Taking milk/ dairy food } & Irregular & $302(64.5 \%)$ \\
\cline { 2 - 3 } & Regular & $90(19.2 \%)$ \\
\cline { 2 - 3 } & Never & $76(16.2 \%)$ \\
\hline Eating junk foods & Irregular & $245(52 \%)$ \\
\cline { 2 - 3 } & Regular & $102(21.7 \%)$ \\
\cline { 2 - 3 } & Never & $124(26.3 \%)$ \\
\hline \multirow{5}{*}{ Drinking water } & Irregular & $269(60.4 \%)$ \\
\cline { 2 - 3 } & Regular & $58(13 \%)$ \\
\cline { 2 - 3 } & Never & $118(26.5 \%)$ \\
\hline & $2-3$ liters/day & $364(72.1 \%)$ \\
\cline { 2 - 3 } & $4-5$ liters/day & $108(21.4 \%)$ \\
\cline { 2 - 3 } & $5-6$ liters/day & $16(3.2 \%)$ \\
\cline { 2 - 3 } & More than 6 liters/day & \\
\hline & & \\
\hline
\end{tabular}

Table 3. Lifestyle behavior of the students.

\begin{tabular}{|l|l|l|}
\hline Variables & Categories & Frequency (\%) \\
\hline \multirow{5}{*}{ BMI } & Underweight & $240(48.7 \%)$ \\
\cline { 2 - 3 } & Normal & $227(46 \%)$ \\
\cline { 2 - 3 } & Overweight & $24(4.9 \%)$ \\
\cline { 2 - 3 } & Obese & $2(0.4 \%)$ \\
\hline \multirow{3}{*}{ Follow Diet } & Yes & $217(42.5 \%)$ \\
\cline { 2 - 3 } & No & $293(57.5 \%)$ \\
\hline \multirow{3}{*}{ Play Sports } & Yes & $274(55.1 \%)$ \\
\cline { 2 - 3 } & No & $223(44.9 \%)$ \\
\hline \multirow{3}{*}{ Extra-curricular activities } & Yes & $252(50.5 \%)$ \\
\cline { 2 - 3 } & No & $247(49.5 \%)$ \\
\hline \multirow{2}{*}{ Use Glasses } & Yes & $104(20.9 \%)$ \\
\cline { 2 - 3 } & No & $393(79.1 \%)$ \\
\hline \multirow{2}{*}{ Social Media } & Yes & $96(19.2 \%)$ \\
\cline { 2 - 3 } & No & $403(80.8 \%)$ \\
\hline \multirow{2}{*}{ Electronic device hamper normal education } & Yes & $258(51.9 \%)$ \\
\cline { 2 - 3 } & No & $239(48.1 \%)$ \\
\cline { 2 - 3 } & Yes & $114(22.8 \%)$ \\
\cline { 2 - 3 } & So & $161(32.2 \%)$ \\
\hline
\end{tabular}


Table 4. Results of multiple Logistic Regression model of Dietary pattern.

\begin{tabular}{|l|l|l|l|l|l|l|l|l|}
\hline \multirow{2}{*}{ Predictor Variables } & \multicolumn{4}{|c|}{} & \multicolumn{2}{|c|}{ 95\% C.I for Exp(B) } \\
\cline { 2 - 10 } & B & S.E & Wald & Df & Sig. & Exp(B) & Lower & Upper \\
\hline $\begin{array}{l}\text { Monthly family income before } \\
\text { pandemic }\end{array}$ & -0.278 & 0.227 & 1.504 & 1 & 0.220 & 0.757 & 0.485 & 1.181 \\
\hline $\begin{array}{l}\text { Monthly family income within } \\
\text { pandemic }\end{array}$ & 0.264 & 0.229 & 1.333 & 1 & 0.248 & 1.303 & 0.832 & 2.041 \\
\hline Reading newspapers & 0.559 & 0.110 & 25.904 & 1 & 0.000 & 1.749 & 1.410 & 2.169 \\
\hline Watching televisions & -0.054 & 0.087 & 0.384 & 1 & 0.535 & 0.948 & 0.800 & 1.123 \\
\hline Connection in social media & 0.220 & 0.203 & 1.170 & 1 & 0.279 & 1.245 & 0.837 & 1.854 \\
\hline Constant & -1.187 & 0.343 & 12.004 & 1 & 0.001 & 0.305 & & \\
\hline
\end{tabular}

\section{Conclusions}

Taken together, it conclude that a considerable percentage (42.5\%) of students in north-eastern part of Bangladesh follow the lifestyle and dietary pattern. There is not so difference was seen between urban and rural students. During COVID-19 pandemic, students intended to do job to help their family as many parents lost their job. To improve the better lifestyle and dietary habits Govt. and NGOs may organize school health program that will help to make awareness in the society about the healthy and unhealthy lifestyle and food habits. Health team of school should take some steps to make an effort to create a behavioral change in young students, and create an environment that provides healthy lifestyle for improving public health sector in Bangladesh.

\section{Acknowledgements}

We would like to thanks the SUST Research Center for funding this study as well as the students who help us providing their information.

\section{Conflict of interest}

None to declare.

\section{Authors' contribution}

Ahsan Habib Sunny and Muhammad Sakib Ibtidha Chowdhury - collected and organized the data with draft analysis and prepared the draft manuscript, and Mohammad Ohid Ullah developed the idea, finalized the data analysis and manuscript. All authors have read and approved the final manuscript.

\section{References}

Ahmed F, A Rahman, AN Noor, M Akhtaruzzaman and R Hughes, 2006. Anaemia and vitamin A status among adolescent schoolboys in Dhaka City, Bangladesh. Public Health Nutr., 9: 345-350.

Anderson PM and KF Butcher, 2006. Childhood obesity: trends and potential causes. Future Child, 16: 19-45.

Banik R, S Naher, S Pervez and MM Hossain, 2020. Fast food consumption and obesity among urban college going adolescents in Bangladesh: a cross-sectional study. Obesity Medicine, 17: 100161.

Bener A, E Yildirim, P Torun, F Çatan, E Bolat, S Alıç, S Akyel and MD Griffiths, 2019. Internet addiction, fatigue, and sleep problems among adolescent students: a large-scale study. International Journal of Mental Health and Addiction, 17: 959-969.

Bhuiyan MU, S Zaman and T Ahmed, 2013. Risk factors associated with overweight and obesity among urban school children and adolescents in Bangladesh: a case-control study. BMC Pediatrics, 13: 1-6.

Bin Zaal, AA, AO Musaiger and R D'Souza, 2009. Dietary habits associated with obesity among adolescents in Dubai, United Arab Emirates. Nutricionhospitalaria, 24: 437-444.

Brug J, MM van Stralen, SJ TeVelde, MJ Chinapaw, I De Bourdeaudhuij, N Lien, and Y Manios, 2012. Differences in weight status and energy-balance related behaviors among schoolchildren across Europe: the ENERGY-project. PloS one, 7: e34742.

Cappuccio FP, FM Taggart, NB Kandala, A Currie, E Peile, S Stranges and MA Miller, 2008. Meta-analysis of short sleep duration and obesity in children and adults. Sleep, 31: 619-626.

Carskadon MA, 1990. Patterns of sleep and sleepiness in adolescents. Pediatrician, 17: 5-12. 
Cavadini C, B Decarli, J Grin, F Narring and PA Michaud, 2000. Food habits and sport activity during adolescence: Differences between athletic and non-athletic teenagers in Switzerland. European Journal of Clinical Nutrition, 54: S16-S20.

Çelebi E, C Gündogdu and A Kizilkaya, 2017. Determination of healthy lifestyle behaviors of high school students. Universal Journal of Educational Research, 5: 1279-1287.

Choi K, H Son, M Park, J Han, K Kim, B Lee and H Gwak, 2009. Internet overuse and excessive daytime sleepiness in adolescents. Psychiatry and Clinical Neurosciences, 63: 455-462.

Cotte J, 1998. Book Review: Time for Life: The Surprising Ways Americans Use Their Time.

Dinges DF, 1995. An overview of sleepiness and accidents. Journal of Sleep Research, 4: 4-14.

Driskell JA, YN Kim and KJ Goebel, 2005. Few differences found in the typical eating and physical activity habits of lower-level and upper-level university students. Journal of the American Dietetic Association, 105: 798-801.

Ekinci Ö, T Çelik, N Savaş and F Toros, 2014. Association between internet use and sleep problems in adolescents. NöroPsikiyatriArşivi, 51: 122.

Fagerli RA and M Wandel, 1999. Gender differences in opinions and practices with regard to a" healthy diet". Appetite, 32: 171-190.

French SA, M Story, D Neumark-Sztainer, JA Fulkerson and P Hannan, 2001. Fast food restaurant use among adolescents: associations with nutrient intake, food choices and behavioral and psychosocial variables. International Journal of Obesity, 25: 1823-1833.

Garaulet M, FB Ortega, JR Ruiz, JP Rey-López, L Beghin, Y Manios, M Cuenca-García, M Plada, K Diethelm, A Kafatos and D Molnár, 2011. Short sleep duration is associated with increased obesity markers in European adolescents: effect of physical activity and dietary habits. The HELENA study. International Journal of Obesity, 35: 1308-1317.

Janssen I, PT Katzmarzyk, WF Boyce, MA King and W Pickett, 2004. Overweight and obesity in Canadian adolescents and their associations with dietary habits and physical activity patterns. Journal of Adolescent Health, 35: 360-367.

Johnson RK, DG Johnson, MQ Wang, H Smiciklas-Wright and HA Guthrie, 1994. Characterizing nutrient intakes of adolescents by sociodemographic factors. Journal of Adolescent Health, 15: 149-154.

Khan A, NW Burton and SG Trost, 2017. Patterns and correlates of physical activity in adolescents in Dhaka city, Bangladesh. Public Health, 145: 75-82.

Kilani H, H Al-Hazzaa, MI Waly and A Musaiger, 2013. Lifestyle habits: Diet, physical activity and sleep duration among Omani adolescents. Sultan Qaboos University Medical Journal, 13: 510.

Ko CH, JY Yen, CF Yen, CS Chen, CC Weng and CC Chen, 2008. The association between Internet addiction and problematic alcohol use in adolescents: the problem behavior model. Cyber Psychology \& Behavior, 11: 571-576.

Kundu S, MSI Khan, J Bakchi, A Sayeed, MHA Banna, MR Begum and MN Hassan, 2020. Sources of nutrition information and nutritional knowledge among school-going adolescents in Bangladesh. Public Health in Practice, 1: 100030.

Law LS, MT MohdNasir and AS Hazizi, 2013. Factors associated with breakfast skipping among school-going adolescents in Sarawak, Malaysia. Malaysian Journal of Nutrition, 19: 401-407.

Lean M, 2010. Health consequences of overweight and obesity in adults. Obesity Epidemiology from Aetiology to Public Health, 2nd edn. Oxford University Press Inc., New York, 43-58.

Lin BH, J Guthrie and E Frazao, 1999. Quality of children's diets at and away from home: 1994-96. Food Review/National Food Review, 22: 2-10.

Munoz KA, SM Krebs-Smith, R Ballard-Barbash and LE Cleveland, 1997. Food intakes of US children and adolescents compared with recommendations. Pediatrics, 100: 323-329.

Musaiger AO and F Kalam, 2014. Dietary habits and lifestyle among adolescents in Damascus, Syria. Annals of Agricultural and Environmental Medicine, 21(2).

Musaiger AO, Z Bader, K Al-Roomi and R D'Souza, 2011. Dietary and lifestyle habits amongst adolescents in Bahrain. Food \& Nutrition Research, 55.

Nahas MV, MVGD Barros, BD Goldfine, ADS Lopes, PC Hallal, JCD FariasJúnior and ESD Oliveira, 2009. Physical activity and eating habits in public high schools from different regions in Brazil: the Saudena Boa project. RevistaBrasileira de Epidemiologia, 12: 270-277.

Neumark-Sztainer D, M Story, MD Resnick and RW Blum, 1998. Lessons learned about adolescent nutrition from the Minnesota Adolescent Health Survey. Journal of the American Dietetic Association, 98: 1449-1456. 
Nielsen SJ, AM Siega-Riz and BM Popkin, 2002. Trends in food locations and sources among adolescents and young adults. Preventive Medicine, 35: 107-113.

Niemeier HM, HA Raynor, EE Lloyd-Richardson, ML Rogers and RR Wing, 2006. Fast food consumption and breakfast skipping: predictors of weight gain from adolescence to adulthood in a nationally representative sample. Journal of Adolescent Health, 39: 842-849.

Ohid Ullah M and RS Tama, 2018. Changes of Food Habits and Body Mass Index of Primary School Going Children in Bangladesh (Submitted).

Ohid Ullah M, A Hasan, MM Rahman, AH Chowdhury, NC Das, J Uddin and MT Uddin, 2014. Obesity of primary school children: a crosssectional study in Bangladesh. International Journal of Scientific \& Engineering Research, 5 (12).

Pearson N and SJ Biddle, 2011. Sedentary behavior and dietary intake in children, adolescents, and adults: a systematic review. American Journal of Preventive Medicine, 41: 178-188.

Rappoport L, GR Peters, R Downey, T McCann and L Huff-Corzine, 1993. Gender and age differences in food cognition. Appetite, 20: 33-52.

Rathi N, L Riddell and A Worsley, 2017. Food consumption patterns of adolescents aged 14-16 years in Kolkata, India. Nutrition Journal, 16: 1-12.

Rennie KL, L Johnson and SA Jebb, 2005. Behavioural determinants of obesity. Best Practice \& Research Clinical Endocrinology \& Metabolism, 19: 343-358.

Serdula MK, D Ivery, RJ Coates, DS Freedman, DF Williamson and T Byers, 1993. Do obese children become obese adults? A review of the literature. Preventive Medicine, 22: 167-177.

Serra-Majem L, L Ribas, J Ngo, RM Ortega, A García, C Pérez-Rodrigo and J Aranceta, 2004. Food, youth and the Mediterranean diet in Spain. Development of KIDMED, Mediterranean Diet Quality Index in children and adolescents. Public Health Nutrition, 7: 931-935.

Sultana N, S Nahar, BC Debnath, MZ Rahman, MQ Naher and SUF Malik, 2011. Prevalence of obesity among the medical students in Sylhet. Jalalabad Med. J., 8: 12-15.

Swinburn BA, I Caterson, JC Seidell and WPT James, 2004. Diet, nutrition and the prevention of excess weight gain and obesity. Public Health Nutrition, 7: 123-146.

Uddin R, A Khan and NW Burton, 2017. Prevalence and sociodemographic patterns of physical activity among Bangladeshi young adults. Journal of Health, Population and Nutrition, 36: 1-9.

Wickramasinghe VP, SP Lamabadusuriya, N Atapattu, G Sathyadas, S Kuruparanantha, and P Karunarathne, 2010. Nutritional status of schoolchildren in an urban area of Sri Lanka. Ceylon Medical Journal, 49(4).

Wolfson AR and MA Carskadon, 1998. Sleep schedules and daytime functioning in adolescents. Child Development, 69: 875-887. 